\title{
Gastrin, Histamine Prostaglandin: Indicators for assessing efficacy of cimetidine, Omeprazole and Ranitidine in Gastric Ulcer Treatment
}

\author{
Jimmy Etukudo Okon ${ }^{*}$, Gideon Umezuruike Egesie ${ }^{2}$ \\ University of Jos, Plateau State, Nigeria
}

${ }^{1}$ Department of Human Physiology, Faculty of Basic Medical Sciences, University of Uyo, Akwa Ibom State, Nigeria

${ }^{2}$ Department of Human Physiology, Faculty of Medical Sciences, University of Jos, Plateau State, Nigeria

\begin{abstract}
Background and Objectives: There is increase prevalence of gastric ulcer in the society, but the drugs that are sensitive for radical cure are not screened with physiologic markers such which affect proper management of the disease. The objective of the study is to relate various sources or organ specific templates: gastrin, histamine and prostaglandin relating with the disease in evaluating the potencies of cimetidine, ranitidine and omeprazole for best choice of the drugs in gastric ulcer disease treatment.
\end{abstract}

Material and Methods: Plasma, gastric and antral prostaglandins, histamine and gastrin levels were studied in ninety-six (96), male and female Swiss albino rats for 28 days, using high performance liquid chromatography.

Results: Male and female rats with gastric ulcer treated with cimetidine, omepraszole and ranitidine showed no significant difference $(\mathrm{P}>0.5)$ in gastrin and the drug groups in plasma, gastric and antral concentrations. But, there was significant difference $(\mathrm{P}<0.05)$ in histamine levels between cimetidine, omeprazole and ranitidine in their gastric and plasma concentration. There was no significant difference $(\mathrm{P}>0.05)$ in prostaglandin values between cimetidine, omeprazole and ranitidine. Also there was no significant difference $(\mathrm{P}>0.05)$ in gastric and plasma levels of gastrin, histamine and prostaglandin between 7, 14, 21 and 28 days treatment period. But, there was significant difference $(\mathrm{P}<0.05)$ in antral concentration of gastrin, histamines and prostaglandin between the drug groups. However, there was no significant difference $(\mathrm{P}>0.05)$ in antral gastrin between male and female rats in cimetidine and ranitidine treatment. The three drugs were associated with high levels of gastrin, histamine, low prostaglandin though cimetidine showed higher concentration of prostaglandin.

Conclusion: It is concluded that gastrin, histamine and prostaglandin are sensitive indicators in evaluating anti-ulcerogenic drugs efficacies.

Key words: Anti-ulcerogenic drugs, gastric ulcer, gastrin, histamine, prostaglandin 


\section{INTRODUCTION}

The gastro-intestinal system is exposed to effects of food, particularly those with high acidic contents, and also drugs like (NSAIDS) Non-steroidal anti-inflammatory drugs, and also gastrin and histamine interactions. And such effects usually result in aberration such as peptic ulcer [1]. Also infection as in Helicobacter pylori is another source of ulcer with it direct effect as in burrowing of gastric barrier and it hydrolyses barrier breaking effect [2]. Peptic ulcer is a salient killer as there are many unrecorded clinical cases and yet there are also high rate in autopsy records [3].

The increase is associated with bleeding, often with high mortality [4].Treatment with $\mathrm{H}_{2}$-blockers; cimetidine, ranitidine is with low results but omeprazole is found to be an effective proton pump inhibitor therapy [5] . But herbal treatment is found to be very effective [6]. Evaluation of efficacy of the drugs with Gastrin, histamine and prostaglandin form the basis of the $\operatorname{drug}(\mathrm{s})$ choice used in this study for efficient management of the disease. Protaglandins, histamine and gastrin are physiological components of the body with many diverse functions necessary for body functioning particularly the gastro-intestinal system.

Protaglandins are autacoids and potent vasodilators formed by the tissues which their actions are manifested [5,7], they are derived from unsaturated fatty acid and arachidonic acid and thought to be derived from prostate, hence the name. There are various types of prostaglandins but the physiologically relevant ones are PGE2, PGF2 [8]. They are produced by the enzymatic degradation of membrane phospholipids, catalyzed by phospholipase A. The enzyme act on phospholipids to form arachidonic acid, while cyclo-oxygenase acts on the arachidonic acid to form protaglandins. It enhances platelet aggregation at tissue damage. It is used in the inducement of labour and abortion [9] e.g. Alfa aprostol while Latanoprostol reduces intraocular pressure [10] . Prostaglandins E and I are widely generated in gastrointestinal tract particularly in the gastric and duodenum [11], its analogue misoprostol has gastric protective properties e.g. ulcer maintenance of mucosal integrity, mucus and bicarbonate production and gastric acid inhibition [12] .

Gastrin is a peptide hormone mainly produced by G-cells in the antral portion of the stomach and as preprogastrin which form the progastrin and by further cleavage of the peptide formed gastrin [13] [14]. There are three types but the physiologic active one is G17 [15]. It is released when food is present in the stomach and in stomach distension. It stimulates the release of hydrochloric acid as it has receptors to parietal cells and enterochromaffin like cells[16] , but it release is inhibited at acidic pH of 3. And increase production of gastrin i.e. hypergastrinaemia leads to gastric ulcer; [1]. Histamine is a chemical messenger that mediate many cellular responses e.g. allergic and inflammatory reactions and in gastrin secretion [17].

It is stored in enterochromatoffin-like cells in the stomach also in basophils, mast cells, skin, lungs, brain epidermis $[5,13]$. The release of histamine lead to its binding to two receptors, $\mathrm{H}_{1}$ and $\mathrm{H}_{2}$, located on cells surfaces have mediation of its action by these receptors. But such actions are inhibited by blockers e.g. $\mathrm{H}_{2}$ antagonists e.g. cimetidine and ranitidine in the treatment of peptic ulcer. The action of these drugs is mediated by its binding on the 
receptors in the parietal cells thus inhibiting the release activity of parietal cells of hydrochloric acid.

In this study, gastrin, histamine, prostaglandin levels were measured using high performance liquid chromatography to assess the efficacy of cimetidine, ranitidine and omeprazole in gastric ulcer treatment. The assessment of these indicators is meant to enhance better management of gastric ulcer as these indicators may deter or enhance therapeutic potencies in the treatment.

\section{MATERIAL AND METHODS}

A total of ninety-six (96) male and female Swiss albino rats were used for the study and each drug group had as flows cimetidine (24 rats), omeprazole (48 rats) and ranitidine (24 rats). The animals were fed with pellets and clean water and kept in a well ventilated university of Jos, animal house. They were cared for according to the regulation of institute of ethical animal committee (IAEC) and all the ethical standard laid down in 1964 declaration of Helsinki were observed.

Inducement of Ulcer: $2.5 \mathrm{ml}$ of ethanol was given per weight for inducement of ulcer after 24 hrs starvation [1].

Drugs Administration: The animals were divided into three drugs groups for the treatment of gastric ulcer. The drugs were administered as follows, cimetidine, $400 \mathrm{mg} / \mathrm{kg}$, ranitidine $300 \mathrm{mg} / \mathrm{kg}$, omeprazole, $20 \mathrm{mg} / \mathrm{kg}$ and were made into powder form and dissolved in $10 \mathrm{ml}$ of water and given orally using canula, by-passing the esophagus and delivered into the stomach [1, 18,19] . The effect of the drugs was observed for 7,14 , 21 and 28 days on gastrin, histamine and protaglandin levels.
Drug Dosages: The concentration of each drug was divided by the average weight of man to arrive at the dosage for animal as follows:

$$
\begin{array}{lll}
\text { Cimetidine }=400 / 70= & 5.7 \mathrm{mg} / \mathrm{kg} . \\
\text { Ranitidine }=300 / 70= & 4.29 \mathrm{mg} / \mathrm{kg} \\
\text { Omeprazole }=20 / 70= & 0.28 \mathrm{mg} / \mathrm{kg}
\end{array}
$$

The dosages in $\mathrm{mg} / \mathrm{kg}$ was taken to the weight of each animal to have the actual concentration per weight of the animal and then divided by the millilitre of water which the drugs were dissolved to have final concentration. Cimetidine and ranitidine were administered twice daily for four weeks, as $\mathrm{H}_{2}$ - blockers while omeprazole was also given twice daily for four weeks as proton pump inhibitor.

\section{Preparation of Plasma, Gastric and Antrum}

Plasma: $5 \mathrm{ml}$ of blood was obtained into EDTA bottle by cardiac puncture [20], using chloroform anesthesia. It was centrifuged at $1200 \mathrm{~g}$ for 10 mins and the plasma aspirated into non-anticoagulant bottles and stored for gastrin histamine and prostaglandin High performance liquid chromatography analysis.

Gastric: The stomach from the anaesthetized sacrificed rats was obtained after opening up the abdomen. It was incised symmetrically and the contents, gastric content obtained by filtration. $20 \mu \mathrm{l}$ was used for Gastrin, histamine and prostaglandin high performance chromatrography analysis.

Antrum: Antrum was obtained between the stomach, and the duodenum it was heat dried using hot plate and homogenized in $10 \mathrm{ml}$ of distilled water. The solutions were stored in $-70^{\circ} \mathrm{C}$ and $20 / \mathrm{ul}$ applied in high performance 
liquid chromatography (HPLC) analysis of gastrin, histamine and protaplandin, for 7, 14, 21 and 28 days.

\section{Preparation of Samples for High Performance Liquid Chromatography (HPLC)}

The high performance liquid chromatography (HPLC) was used to quantitate Gastrin, histamine and prostaglandin. It was 1100 series agilent with thermostated column compartment G1316A (Germany), VWD detector (UV) Zorbax RXDBC18(150 X 4.0), 5um pore size. The quaternary pump, G1314A (Germany), degasser, G1379A (Japan) and Rheodyne injector (20) USA. It was an automated system driven at the speed of 100 megabite per second. The columns used were, Zorbax for gastrin and histamine and Hyprisil for prostaglandin.

Samples collected from plasma, gastric antrum were pretreated with acetonitrite for removal of proteins, $1 \mathrm{ml}$ of each of the samples were treated with $2 \mu$ l of acetonitrite. It was shaken for $1 \mathrm{~min}$. The mixture precipitated and the precipitate spun to obtain clear supernatant. $20 \mu \mathrm{l}$ of the supernatant was injected into the HPLC.

$50 \mathrm{ml}$ of ethanol were added as mobile phase for affinity separation of the molecules and their final elution based on their interactions with the stationary phases; the zorbax silica and hyprisil at solid phases and flow rate of $1 \mathrm{ml} / \mathrm{min}$. Standard of the gastrin, histamine and prostaglandin levels were used in determining the concentration of each by calculating test results by standard. The instructions of the manufacturer were followed.

\section{RESULTS}

Effects of Cimetidine, Omeprazole \& Ranitidine on Plasma Gastrin, Histamine/Prostaglandin: Male and female rats with gastric ulcer treated with cimetidine, omeprazole and ranitidine showed no significant difference in plasma gastrin between the drug groups, $(\mathrm{p}>0.05) \mathrm{P}$ $=0.14$, table I. But there was significant difference $(\mathrm{P}<0.05)$ in histamine value between cimetidine, omeprazole and ranitidine, at $\mathrm{p}=0.001$. There was no significant difference $(p>0.05)$ in prostaglandin values between cimetidine, omeprazole and ranitidine, $\mathrm{p}=6$. 37. And there was no significant difference. $(\mathrm{P}>0.05)$ in plasma gastrin, histamine and prostaglandin values between 7, 14, 21 and 28 days, at $\mathrm{p}=0.861$.

There was a very strong positive correlation $(r=0.86)$ between gastrin in cimetidine and histamine in ranitidine treatment but very weak negative correlation $(-0.072)$ between gastrin in cimetidine and gastrin in ranitidine treatment. But there was an average positive correlation $(r=0.459)$ between gastrin in omeprazole and histamine and cimetidine treatment. Also a weak correlation (-0.39) existed between gastrin in omeprazole treatment and prostaglandin in ranitidine treatment. However, there was average positive correlation $(\mathrm{r}=0.461)$ between gastrin in ranitidine and prostaglandin in omeprazole treatment. Also weak negative correlation $(-0.36)$ existed between gastrin in ranitidine treatment and prostaglandin in cimetidine treatment.

Effects of Cimetidine Omeprazole and Ranitidine on Antral Gastrin, Histamine and Prostaglandin 
Male and female rats treated with cimetidine, omeprazole and ranitidine showed significant difference $(\mathrm{p}<0.05)$, in antral gastrin, histamine and prostaglandin between the drugs groups at $p=0.002$. But there was no significant difference in antral gastrin between male and female rats treated with cimetidine, $(p>0.05)$, at $p=0.66$. Also there was no significant difference between male and female rats in antral gastrin in ranitidine treatment $(p>0.05)$ at $p=0.42$.

\section{DISCUSSION}

The gastrointestinal profiles: gastrin, histamine and prostaglandin analyzed from the plasma, gastric and antrum showed different concentrations and such variations are organ dependent. The results showed higher concentration of gastrin in the antrum than in the plasma and gastric because it is produced in the antrum [21]. The next higher concentration was histamine and the least was prostaglandin. In this study gastrin, histamine and prostaglandin were studied concurrently in plasma, antrum and gastric. However, the variations of the gastrin, histamine and protaglandin were dependent on the drugs for the treatment of ulcer, cimetidine, omeprazole and ranitidine. Also concentrations were a function of the disease state gastric ulcer. Rats with gastric ulcer were found to have low prostaglandin levels indicating the role of prostaglandin in the pathogenesis of peptic ulcer; confirming previous work [11].

High performance liquid chromatography was used in the analysis of gastrin, histamine and prostaglandin; a more sensitive method. However, the presence of histamine in G-cells of the rat stomach has been analyzed indirectly by the use of histidine

\begin{tabular}{|c|c|c|c|c|c|}
\hline \multicolumn{2}{|c|}{ Period } & $\begin{array}{l}7 \\
\text { days }\end{array}$ & $\begin{array}{l}14 \\
\text { days }\end{array}$ & $\begin{array}{l}21 \\
\text { days }\end{array}$ & $\begin{array}{l}28 \\
\text { days }\end{array}$ \\
\hline \multicolumn{6}{|c|}{ Cimetidine } \\
\hline $\begin{array}{l}\mathrm{GT} / \mathrm{M} \\
\mu / \mathrm{ml}\end{array}$ & & 0.0 & 37.0 & 61.8 & 100 \\
\hline $\begin{array}{l}\text { GTF } \\
\mu / \mathrm{ml}\end{array}$ & & 0.6 & 22.2 & 71.3 & 98.0 \\
\hline $\begin{array}{l}\text { HTM } \\
\mu / \mathrm{ml}\end{array}$ & & 50.7 & 45.2 & 48.0 & 50.6 \\
\hline $\begin{array}{l}\text { HTF } \\
\mu / \mathrm{ml}\end{array}$ & & 48.7 & 38.5 & 40.6 & 50.3 \\
\hline $\begin{array}{l}\mathrm{PGM} \\
\mu / \mathrm{ml}\end{array}$ & & 560.3 & 713.8 & 656.1 & 712.0 \\
\hline $\begin{array}{l}\text { PGF } \\
\mu / \mathrm{ml}\end{array}$ & & 525.5 & 505.4 & 656.0 & 632.2 \\
\hline \multicolumn{6}{|c|}{ Omeprazole } \\
\hline $\begin{array}{l}\mathrm{GT} / \mathrm{M} \\
\mu / \mathrm{ml}\end{array}$ & & 100.2 & 62.0 & 54.1 & 79.6 \\
\hline $\begin{array}{l}\text { GTF } \\
\mu / \mathrm{ml}\end{array}$ & & 96.6 & 72.1 & 48.2 & 61.7 \\
\hline $\begin{array}{l}\text { HTM } \\
\mu / \mathrm{ml}\end{array}$ & & 25.7 & 40.2 & 18.2 & 25.1 \\
\hline $\begin{array}{l}\text { HTF } \\
\mu / \mathrm{ml}\end{array}$ & & 20.2 & 31.1 & 15.2 & 28.2 \\
\hline $\begin{array}{l}\text { PGM } \\
\mu / \mathrm{ml}\end{array}$ & & 560.3 & 542.5 & 796.6 & 887.1 \\
\hline $\begin{array}{l}\text { PGF } \\
\mu / \mathrm{ml}\end{array}$ & & 500.7 & 463.7 & 448.1 & 497.9 \\
\hline \multicolumn{6}{|c|}{ Ranitidine } \\
\hline $\begin{array}{l}\mathrm{GT} / \mathrm{M} \\
\mu / \mathrm{ml}\end{array}$ & & 50.6 & 46.1 & 50.2 & 51.8 \\
\hline $\begin{array}{l}\text { GTF } \\
\mu / \mathrm{ml}\end{array}$ & & 48.1 & 52.6 & 45.7 & 48.2 \\
\hline $\begin{array}{l}\text { HTM } \\
\mu / \mathrm{ml}\end{array}$ & & 25.6 & 40.8 & 48.1 & 45.6 \\
\hline $\begin{array}{l}\text { HTF } \\
\mu / \mathrm{ml}\end{array}$ & & 20.2 & 36.1 & 40.1 & 46.2 \\
\hline $\begin{array}{l}\text { PGM } \\
\mu / \mathrm{ml}\end{array}$ & & 257.3 & 292.2 & 393.2 & 397.6 \\
\hline $\begin{array}{l}\text { PGF } \\
\mu / \mathrm{ml}\end{array}$ & & 234.4 & 243.3 & 268.0 & 472.6 \\
\hline GTM & $=$ & \multicolumn{4}{|c|}{ Gastrin } \\
\hline HTF & $=$ & \multicolumn{4}{|c|}{ Histamine } \\
\hline$P G$ & $=$ & \multicolumn{4}{|c|}{ Prostaglandins } \\
\hline Cimeti & & \multicolumn{4}{|c|}{ Male and female $n=24$} \\
\hline Omepr & ble: & \multicolumn{4}{|c|}{ Male and female $\mathrm{n}=48$} \\
\hline Ranitic & & \multicolumn{4}{|c|}{ Male and female $n=24$} \\
\hline GTM & $=$ & \multicolumn{4}{|c|}{ Gastrin in males } \\
\hline GTF & $=$ & \multicolumn{4}{|c|}{ Gastrin in females } \\
\hline HTM & $=$ & \multicolumn{4}{|c|}{ Histamine in males } \\
\hline HTF & $=$ & \multicolumn{4}{|c|}{ Histamine in females } \\
\hline PGM & $=$ & \multicolumn{4}{|c|}{ Prostaglandin males } \\
\hline
\end{tabular}


Table 2: Effects of Cimetidine, and Ranitidine on antral Gastrin, Histamine and Prostaglandins in Male and Female Rats With Gastric Ulcer - Summary for 28 Days

\begin{tabular}{|c|c|c|c|c|c|c|}
\hline Drugs & \multicolumn{2}{|c|}{ Gastrin (mg/ml) } & \multicolumn{2}{|c|}{ Histamine (mg/ml) } & \multicolumn{2}{|c|}{ Prostaglandins $(\mathrm{mg} / \mathrm{ml})$} \\
\hline \multirow{2}{*}{ Cimetidine } & $\mathbf{M}$ & $\mathbf{F}$ & $\mathbf{M}$ & $\mathbf{F}$ & $\mathbf{M}$ & $\mathbf{F}$ \\
\hline & 1031.6 & 1030.8 & 1046.9 & 1047.6 & 421.2 & 420.6 \\
\hline Ranitidine & 0.00000 & 0.00000 & 1358.2 & 1366.3 & 1.12 & 1.14 \\
\hline $\begin{array}{l}\text { Control without } \\
\text { ulcer }\end{array}$ & 474.6 & 475.2 & 1106.7 & 997.6 & 264.9 & 266.0 \\
\hline Cimetidine: & \multicolumn{2}{|c|}{ Male/Female } & \multicolumn{2}{|c|}{24} & & \\
\hline Ranitidine: & \multicolumn{2}{|c|}{ Male/Female } & \multicolumn{2}{|c|}{2} & & \\
\hline
\end{tabular}

decarboxylase enzyme assay [22] and not with high performance liquid chromatography. Histamine presence in antral G- cells will act locally as autocrine stimulator or inhibitor of gastrin secretion as activation of $\mathrm{H}_{3}$ receptors reduces gastric acid secretion. Prostaglandin, also inhibit hydrochloric acid synthesis but increase mucus synthesis which will act against gastric activity [23].

The results suggest that the antrum derived histamine in the study may inhibit gastrin secretion mainly as negative feedback mechanism to gastrin acid secretion properties. However, the reduction of gastrin secretion may in turn affect the histamine production i.e. it will reduce it secretion from the enterochromaffin-like cells. The autoregulatory effects will dwell mainly on $\mathrm{H}_{2}$ and $\mathrm{H}_{3}$ receptors directly involve in secretion and are important in auto regulatory effect of antral G-cells histaminergic properties [24].

But antral G-cells derived histamine may stimulate gastrin secretion and may also contribute to its secretory activities in the fundus. It may reach target cells in the fundus in the stomach and produce acid stimulatory effects on the parietal cells. The findings in this study are that the sharing of the common organ and cellular origin of gastrin with histamine and prostaglandin is a physiologic approach for histamine and prostaglandin to regulate the generalized effects of gastrin secretion from the stomach fundus.

The spread of gastrin, histamine and prostaglandin is for additional effect on the gastrin secretion at source, with histamineric activities on the parietal cells as the direct effect of gastrin is controlled at source; the antral G-cells. Histamine concentration was high in cimetidine and ranitidine treatment but low in omeprazole. This confirms the therapeutic efficacy of omeprazale over the two drugs.

The gastrin histamine and prostaglandin studies have shown them as indicators or markers for the screening of the efficacy of anti-ulcerogenic drugs. It is therefore advisable to use high performance liquid chromatography to evaluate drugs effectiveness of anti-ulcerogenic drugs where the management of this disease may get more complicated with use of other antiulcerogenic drugs.

\section{CONCLUSION}

The study has shown that the use of gastrin, histamine and prostaglandin and their concentrations have indicated most physiologically friendly anti-ulcerogenic drugs. 


\section{ACKNOWLEDGEMENT}

All the technologists in the University of Jos are acknowledged. Others are Dr E Ekwere, Department of Anatomy and Mrs O Idah of Department of Physiology, all of University of Jos

\section{AUTHOR'S CONTRIBUTION}

EOJ \& GUE- The research and write up were done by the authors.

SOURCE OF SUPPORT: Department of Physiology, University of Jos.

CONFLICT OF INTEREST: There is no conflict of interest

\section{REFERENCES}

1. Jimmy EO, Odeh SO, Adelaiye AB. Hypergastrinaemia and Raised HCL in tea drinking associated gastric ulcer. Journal of Physiolo-biochemical and metabolism 2013; 2:(2) 2 - 4 .

2. Fong SY, Wong YC, Vic C, Zko Z. Herb-drug interactions between scuteruarrieze and mefenamic acid, simultaneous investigation of pharmacokinetics and anti-inflammatory effects and gastric damage in journal of Ethnopharmacology 2015; 170:101-16.

3. Olubuyide IO. An autopsy survey of peptic ulcer disease at Ibadan. African journal of medicine 1989;35: (10) 1-6.

4. Tang SJ. Endoscopic treatment of upper gastrointestinal ulcer bleeding, video journal of encyclopedia, GI endoscopy 2013; 1:(1) 143 $-147$.

5. Tripathi KD, Editor. Essentials of Medical Pharmacology. $6^{\text {th }}$ ed Ajanta. New Delhi, 2008. pp 150-160

6. Jimmy EO. Novel compounds with antiulcerogenic potentials unveiled in plantain leaves isolates( Musa paradisciaca). Journal of drug discovery and therapy 2017; 5: (2) 39-42

7. Main IH, Whittle BJR. Effects of prostaglandins E2 on rat gastric mucosal blood flow as determined by c-aniline clearance British journal of pharmacology $1972 ; 49534-542$.
8. Mcguffin V.L, Zare RN. ( femtomole analyzing of prostaglandins pharmaceuticals. Natl. acad.sci. 1985; 82: 8315 -19.

9. Maral NE, Aslan S, Findik M. Induction of abortion in queens by administration of carbergoline solely or in combination with PGF2 an analogy Alfaprostal. Thenogenologyi 2004; 61: (7-8) 1471 -5.

10. EMDEX, The complete drug formulary for Nigerians Health Professionals. Lindox book Canda. 2006 pp 103-109

11. Konturex SJ. Prostaglandins in Pathophysiology of peptic ulcer disease journal of digestive diseases and sciences 1985; 30:(11) 1056 - 1058.

12. Danjani E, Agrawal N.M.. Protective effects of prostaglandins against antinflamation drug induced gastrointestinal injury Int. J din Pharmaed 1989; 9:(6) 359-69.

13. Oyebola D 0 , editor. Textbook of essential physiology vol.1. $1^{\text {st }}$ ed Oxford Press, Ibadan 2002. pp 1-244

14. Dockary G J. Gastrin best practice and Research. Clinical endocrinol 2004; 18:(4) $555-568$.

15. Osim EE. Editor. Elements of gastrointestinal tract physiology. Vol.1, 2002. pp. $1-105$.

16. Chen D, Zhao CM, Haider W, Hakanson R, Rehfield JF, Kopsin AS. Differentiation of gastric Ecl cells is altered in CCK receptor deficient mice: Gastroenterology 2002; 123: $577-555$.

17. Kazuharu F, Takeshi A, Eiji N et al Crucial role of histamine for regulation of gastric acid secretion ascertained by histamine decarboxylase. Journal of pharmacology and experimental therapeutic 2003; 307:331.

18. Bertram G K, editor. Basic and clinical Pharmacology. $9^{\text {th }}$ ed. Lange. New York. 2004. pp 14-44

19. Robert G. Gastric cytoprotective properties of prostaglandins. Gastroenterol 1979;77: 762 769.

20. Dacie \& Lewis. Editor. Practical Haemathogy. 10 th ed Elsevier.churchil, 2007.pp1-8

21. Guyton AC, John HE. Text book of Medical physiology. 22nd ed Elsvier, Philadelphia.2011. pp 776-799

22. Canonia G, Walter B \& Michael. in wikipedia, 2011.Ng.

23. Nylaander O, Anderson H, Wilander E, Sababi M. Prostaglandins reduce hydrochloric acidinduce increase in duodenal mucosal 
permeability by a mechanism not related to stimulation of alkaline secretion. Acta Physiol. 1955; 153:(4) 365-74.

24. Cianchi F, Cortesini C, schiarone N. et al. The role of cycloxygrenase \& in mediating the effects of histamine in cell preparation and vascular endothedial growth factor production in colorectal cancer. clinical cancer Research 2005; (11) 6807 - 6815.

25. World Medical Association declaration of Helsinki 1964 ( ethical principles for medical research).

Correspondence to:

Prof. Jimmy Etukudo Okon

Department of Human Physiology

University of Jos, Plateu State, Nigeria

Email: medstedrecheo@yahoo.com 